\title{
Insights of women's empowerment and decision-making in rice production in Malaysia
}

\author{
Amran, F.N.F. and *Abdul Fatah, F. \\ Faculty of Plantation and Agrotechnology, Universiti Teknologi MARA (UiTM), Cawangan Melaka Kampus \\ Jasin, 77300 Merlimau, Melaka, Malaysia
}

\section{Article history: \\ Received: 22 July 2020 \\ Received in revised form: 28 \\ October 2020 \\ Accepted: 11 December 2020 \\ Available Online: 20 \\ December 2020}

\section{Keywords:}

Agriculture,

Food security,

Decision-making,

Rice,

Women's empowerment

DOI:

https://doi.org/10.26656/fr.2017.4(S5).013

\begin{abstract}
Women's empowerment is essential in achieving global food security while being prioritised as one of the Sustainable Development Goals (SDG) agenda. Even though a women's empowerment role in agriculture received wide attention in works of literature, there is still a research gap about women's empowerment in Malaysia's agriculture. This study contributes to the status of women's empowerment and its determinants, as well as challenges to enhance women's empowerment among rice smallholders in Selangor, Malaysia. By using a framework adapted from the Women's Empowerment in Agriculture Index (WEAI), 200 smallholder paddy farmers were selected using stratified random sampling. The results revealed vital domains that contributed to women's empowerment, which provided access to extension services and led to effective decision-making, whereas leadership displayed a negative association. The lack of participation in the planning process and community groups were significant obstacles in enhancing the women's empowerment among rice farmers. These results suggested the scope of possible interventions and policy recommendations to enhance women's empowerment in agriculture.
\end{abstract}

\section{Introduction}

Rice is produced in over 112 countries worldwide and the world's third-largest agricultural commodity behind sugarcane and maize with China and India being the two largest rice producers, which produce over 146 and 103 million tons of rice, respectively (Abaide et al., 2019). In Malaysia, rice cultivation is an old, heavily protected, and subsidised industry. Rice is a nutritious staple containing starch (carbohydrates), providing significant calorie to Malaysians (Muazu et al., 2015). Due to its significance to the Malaysian economy, the Malaysian paddy industry receives special consideration such as a monopoly on imports, controlled prices for milling, wholesale, and retail rice, provision of fertilizer subsidies, price support, drainage and irrigation facilities and others (Shamsudin et al., 2015; Abdul Fatah and von -Cramon Taubadel, 2017). In the Malaysian society, rice cultivation is crucial for promoting agricultural activities and helping to feed a growing population, with the Malaysians' rice consumption of an average two and a half plates per day (Rajamoorthy et al., 2015; Aris and Abdul Fatah, 2019).

In the agriculture sector, women actively engaged in a wide variety of tasks related to cultivation (Haimid et $a l ., 2016)$. They produced more than 50 per cent of the world's food and contributed to approximately $43 \%$ of the world's agricultural labour force (Akter et al., 2017). As in other parts of Asian countries, women were vital in the production of staple food and engaged in various tasks related to cultivation (Singh et al., 2015). Nevertheless, their essential role in farming and improving the quality of rural areas often remain hidden due to insufficient empowerment for women (Haimid et al., 2016). The role of the women's empowerment in agriculture received wide attention in the recent decade (Bhat, 2015; Akter et al., 2017; Diiro et al., 2018), despite existing research gaps regarding the subject in Malaysian agriculture with limited attention given on that matter. Furthermore, women in the Malaysian agriculture sector statistically recorded negative growth, and they face barriers to accessing resources and productivity in the agriculture sector (Haimid et al., 2016).

Many dimensions of the status of women include control of resources by women, independence, decisionmaking capacity, self-esteem, and mental health, can be collectively defined as the aspects of empowerment by 
women (Holland and Rammohan, 2019). Their ability to participate and influence decisions that affect their household and farming lives was considered one of the main components of empowerment (Ganle et al., 2015). Agricultural empowerment is generally defined as an individual's capacity for decision-making on agricultural issues and access to the material and social resources needed to make those choices (Alkire et al., 2013). On the other hand, Ragsdale et al. (2018) stated that smallholder farmers of men and women frequently had different requirements and priorities along with access to resources such as credit, training for extensions, and new technologies. Studies also showed that crop yields among the female smallholder farmers were lower than the male, albeit growing similar crops in the same season. This idea was a factor of limited access to agricultural inputs, extension services, credit, and market among the female smallholder farmers, which ultimately affected their crop yields (Quisumbing et al., 2001; Goldstein and Udry, 2008; Peterman et al., 2011; Kilic et al., 2013).

Women's empowerment is objectively crucial for the 2030 Sustainable Development Agenda, as females in all parts of the world continue to suffer significant discrimination (Yount et al., 2019). Considering the scarcity of women's empowerment studies in Malaysia, this research is relevant to achieve the 2030 Sustainable Development Goal 5 (SDG5) in prioritising women's empowerment (Alkire et al., 2013). Therefore, this research aims to generate a better understanding of women's empowerment among rice farmers in Malaysia. This study contributes to the status of women's empowerment, factors affecting women's empowerment, and challenges to increase women's empowerment among smallholder rice farmers in Selangor, Malaysia.

This study used an adapted version of Women's Empowerment in Agriculture Index (WEAI); a surveybased index reported based on individual-level data gathered from male and female respondents (Alkire et al., 2013). The WEAI, jointly developed by the United States Agency for International Development (USAID), International Food Policy Research Institute (IFPRI), and the Oxford Poverty and Human Development Initiative (OPHI), is the first systematic and structured indicator to identify women's empowerment in agriculture explicitly (Akter et al., 2017). The WEAI was adapted with modifications that consisted of five factors. Firstly, the extension services measured the decision-making over training provided and involvement of farmers in a community-based activity. The second factor was land and resources that captured the decision-making power of individuals over productive resources, such as land and farm equipment. The third factor was leadership, measured through economic or social participation and the comfort of public speaking. Time and drudgery were measured by the time distribution of the farmer between productive and household duties and leisure activities. Finally, credit and income were measured through the control of income and expenditure utilisation, budget management, and credit decision.

\section{Materials and methods}

\subsection{Study area}

This study was performed in Selangor's rice cultivation under the Integrated Agricultural Development Area (IADA) Barat Laut, Selangor (BLS). IADA BLS comprised nine blocks, which include Sawah Sempadan, Sungai Burong, Sekinchan, Sungai Leman, Pasir Panjang, Sungai Nipah, Pancang Bedena, Bagan Terap, and Sungai Panjang. IADA BLS first opened in 1936 covering 20,000 hectares of irrigation. During its first implementation, rice growers used water source from Sungai Bernam, Sungai Tengi, and rainwater as irrigation until the early 1960's when the granary area was introduced to enhance the irrigation area to reach double cropping with an average yield of $2.5 \mathrm{mt} / \mathrm{ha}$ (Alam et al., 2010). Presently, the total paddy cultivation area in IADA BLS is estimated to reach 19,057 hectares with 9,693 total farmers and approximately 4.5 to 7.0 ton/ha of paddy production. The focus of development for IADA BLS involved all agricultural infrastructure development activities, including existing agricultural area, crop, and population and human capital as well as equipment needs and food processing facilities. Figure 1 shows the location of the study area

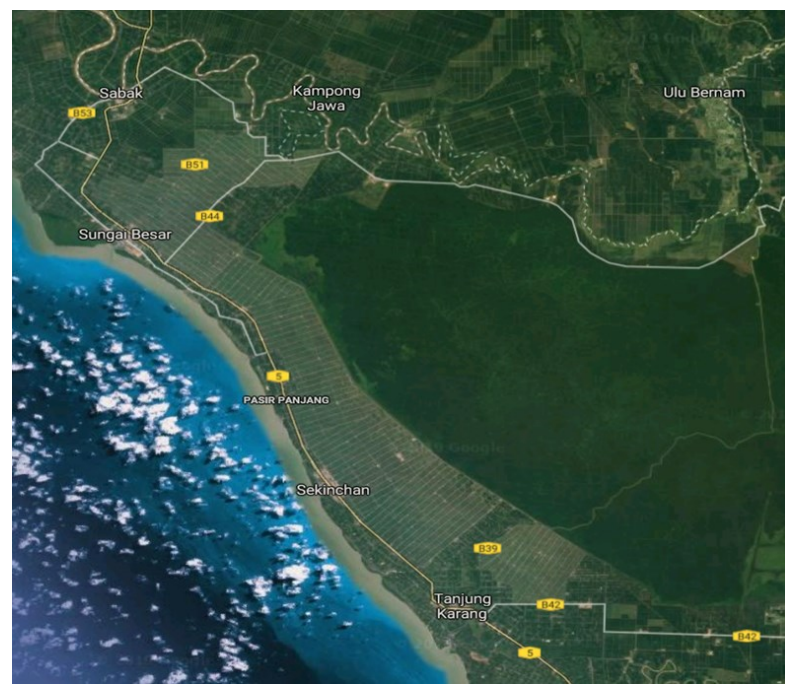

Figure 1. Location of IADA BLS.

\subsection{Method and data collection}

\subsubsection{Sampling technique}

By using stratified random sampling, 200 
smallholder rice farmers comprising 100 males and 100 females were selected in this study. A stratified random sampling divided the population into subgroups or strata, and random samples obtained in proportion to the population of each stratum. The members formed in each stratum shared similar attributes and characteristics. This sampling method was widely used and suitable for a heterogeneous target population. In this study, a proportionate number of male and female farmers were selected for the sample. The objective of a stratified random sample was, to reduce the potential human bias in the selection of cases to be included in the sample. Since the survey was restricted to only rice farmers in IADA, our sample was not nationally representative. The survey questionnaire was locally pre-tested several times and gathered information on the household characteristics, including demographics of all household members and detailed information on farming practices.

The survey's key objective was identifying the farmers' psychographic characteristics to develop agricultural interventions, which targeted their underlying motivations and challenges toward farming. The male and female households were enumerators for "the adult responsible for the organisation and care for the household or have assumed the role of the head of household considered by the household's members". On the other hand, a spouse represented either "a male or female farmer along with their husband or wife, who identified themselves as rice farmers and the decisionmaking processes were managed jointly by the principal female and male households" (Diiro et al., 2018). The male head of household answered all the questions in the survey, while both spouses separately answered a subset of questions that included personal information, attitude toward farming and risk, and perceptions of decisionmaking authority. To reduce response bias, specifically from cultural norms or expectations, individual spouses were separately interviewed.

\subsubsection{Data collection}

In this research, data were collected from rice farmers using well-structured and close-ended questionnaire via a face-to-face survey. The instrument used for data collection comprised of four sections of A, B, C, and D. Section A included questions or items on demographic variables, such as age, marital status, level of education, family member, experience, and income. Section B dealt with the role of women in rice production and their decision-making on land preparation, pesticide application, fertiliser spraying, weeding, harvesting, and marketing. Section $\mathrm{C}$ covered the factors affecting women's empowerment among farmers (decision-making on production/significant roles played by rice farmers), including their access to extension service, land/resources, leadership, time and drudgery, and credit/income. Finally, Section D discussed challenges in enhancing the empowerment of women in agriculture, which included the lack of participation in the planning process and community programmes, poor access to finance and credit, lack of training and extension services, lack of access to agricultural information and technology, and low socioeconomic factors. The questionnaires were adapted from Alkire et al. (2013) and Gupta (2016) with modifications.

\subsection{Analytical approach}

\subsubsection{Descriptive analysis}

Descriptive analysis was used in this study to summarise the respondent's demographic data, such as marital status, age, educational level, family member, and experience. Additionally, it was also used to enlighten women's empowerment's challenges and its status.

\subsubsection{Regression analysis}

Multinomial logistic regression (often referred to as 'multinomial regression') was used to determine the factors affecting the women's empowerment among rice farmers and forecasted a nominal dependent variable with one or more independent variables. Often, the extension of binomial logistic regression was considered to allow a dependent variable with more than two categories. Multinomial logistic regression may have nominal and continuous independent variables and interactions among independent variables to predict the dependent variable.

The standard linear regression required the dependent variable to be assessed on a continuous (interval or ratio) scale. Binary logistic regression presumed that the dependent variable was stochastic. The dependent variable described the outcome of this stochastic event with a density function (a function of the cumulative probabilities ranging from 0 to 1 ). The cutoff point (e.g. 0.5) were used to determine which outcome was predicted by the model based on the predictor values. The equation below presents the multinomial logistic regression linear model:

$$
\eta_{i j}=\log \frac{\pi_{i j}}{\pi_{i j}}=\alpha_{j}+x_{i}^{\prime} \beta_{j}
$$

Where $\eta_{i j}$ was a binary dependent variable $(1=$ femaleheaded, $0=$ male-headed households or $1=$ spouse, $0=$ male-headed households). $\alpha \mathrm{j}$ was a constant and $\beta \mathrm{j}$ was the vector of regression coefficients, for $\mathrm{j}=1,2, \ldots, \mathrm{j}-1$. While $\quad x_{i}^{\prime}$ represented five major factors that affected women's empowerment, namely extension service, land and resources, leadership, time and 
drudgery, and credit/income.

\section{Results and discussion}

\subsection{Socio-economic factors}

Table 1 displays the summary of demographic variables, including age, experience, education, household size, marital status, occupation, and income. Approximately $54 \%$ of the respondents were aged between 51 to 75 , which accounted for 108 farmers. Majority of the respondents were married $(n=180$, $90 \%)$, completed secondary school $(\mathrm{n}=106,53 \%)$, and possessed a household size between 4-6 members ( $\mathrm{n}=$ $110,55 \%)$. Almost all of the respondents had more than 15 years of experience $(n=92,46 \%)$ and earned an income between RM2001 and RM3000 ( $\mathrm{n}=70,35 \%)$.

Table 1. Socio-economic factors

\begin{tabular}{|c|c|c|}
\hline Variables & Frequency & Percentage $(\%)$ \\
\hline \multicolumn{3}{|l|}{ Gender } \\
\hline Male & 100 & 50 \\
\hline Female & 100 & 50 \\
\hline \multicolumn{3}{|l|}{ Age } \\
\hline Below 25 & 7 & 3.5 \\
\hline $26-50$ & 76 & 38 \\
\hline $51-75$ & 108 & 54 \\
\hline Above 76 & 9 & 4.5 \\
\hline \multicolumn{3}{|l|}{ Marital status } \\
\hline Single & 20 & 10 \\
\hline Married & 180 & 90 \\
\hline \multicolumn{3}{|l|}{ Education level } \\
\hline No education & 10 & 5 \\
\hline Primary school & 82 & 41 \\
\hline Secondary school & 106 & 53 \\
\hline University/college & 2 & 1 \\
\hline \multicolumn{3}{|l|}{ House size } \\
\hline Below 3 & 69 & 34.5 \\
\hline $4-6$ & 110 & 55 \\
\hline $7-9$ & 20 & 10 \\
\hline Above 10 & 1 & 0.5 \\
\hline \multicolumn{3}{|l|}{ Experience } \\
\hline Below 5 & 8 & 4 \\
\hline $6-10$ & 32 & 16 \\
\hline $11-15$ & 68 & 34 \\
\hline Above 16 & 92 & 46 \\
\hline \multicolumn{3}{|l|}{ Income } \\
\hline Below 2000 & 27 & 13.5 \\
\hline $2001-3000$ & 70 & 35 \\
\hline $3001-4000$ & 63 & 31.5 \\
\hline Above 4000 & 40 & 20 \\
\hline
\end{tabular}

3.2 Women's role and decision-making in rice production

Table 2 shows the information on the roles of women and their decision-making in Malaysian rice production. Notably, there were common trends that divided labours between male and female farmers. Males dominated most of the major tasks and decisions, while other tasks were determined by the female-headed household or both spouses on rice farming activities. Some participants acknowledged that instead of individual decisions, spouses collectively made their decisions, such as water management, while a community farmer's group made other decisions. The decisions from the farmers' group were essential and based on a water management's schedule or irrigation by blocks to ensure sufficient water for rice growth for all areas.

Table 2. Women's role and decision-making in rice production

\begin{tabular}{|c|c|c|c|c|c|c|}
\hline \multirow[t]{2}{*}{ Decision } & \multicolumn{2}{|c|}{ 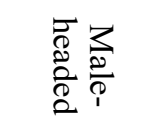 } & \multicolumn{2}{|c|}{ 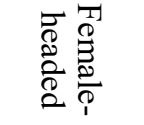 } & \multicolumn{2}{|c|}{$\begin{array}{l}\tilde{y} \\
\overline{8} \\
\tilde{D} \\
0\end{array}$} \\
\hline & $\mathrm{N}$ & $\%$ & $\mathrm{~N}$ & $\%$ & $\mathrm{~N}$ & $\%$ \\
\hline Land preparation & 114 & 57 & 38 & 19 & 48 & 24 \\
\hline Pesticide application & 130 & 65 & 42 & 21 & 28 & 14 \\
\hline Fertiliser spraying & 118 & 59 & 44 & 22 & 38 & 19 \\
\hline Weeding & 54 & 27 & 76 & 38 & 70 & 35 \\
\hline Harvesting & 30 & 15 & 24 & 12 & 146 & 73 \\
\hline Marketing & 38 & 19 & 10 & 5 & 152 & 76 \\
\hline
\end{tabular}

The largest contributions of decision-making by male-headed household included land preparation ( $\mathrm{n}=$ $115,57 \%)$, pesticide application $(\mathrm{n}=130,65 \%)$, and fertiliser spraying $(\mathrm{n}=118,59 \%)$. Most female farmers hired workers to perform labour intensive tasks in rice farming, such as pesticide application and fertiliser spraying, albeit some female farmers performed similar tasks independently. Land preparation was primarily conducted by males, such as land clearing, weeding, preirrigation, ploughing, and harrowing and levelling. Contrastingly, female farmers mentioned that they were only involved in clearing the paddy bund and small weed. Furthermore, the transplanting was mostly mechanically performed in IADA BLS. Weeding practice was the largest proportion of women's participation in rice farming decision-making $(\mathrm{n}=76,38$ $\%)$. Female farmers spent more time on weeding during the rice cultivation process, while some of them hired labourers. Correspondingly, harvesting $(n=146,73 \%)$ and marketing $(\mathrm{n}=152,76 \%)$ decisions were dominated by the spouse. Although farmers carried out manual harvesting, both male and female farmers had to hire additional workers to perform the task when the combine harvester was used.

\subsection{Factors affecting women's empowerment among rice farmers}

\subsubsection{Female-headed versus male-headed decision- making}

Table 3 presents the factors affecting women's 
Table 3. Female-headed and spouse-headed versus male-headed decision-making

\begin{tabular}{lcccccc}
\hline \multirow{2}{*}{ Decision } & \multicolumn{3}{c}{ Female-headed } & \multicolumn{3}{c}{ Spouse-headed } \\
\cline { 2 - 7 } & Coefficient & Std. Error & p-value & Coefficient & Std. Error & p-value \\
\hline Extension & $0.765^{*}$ & 0.393 & 0.052 & $1.551^{* * *}$ & 0.536 & 0.004 \\
Land and resources & -0.262 & 0.414 & 0.527 & $1.254^{* *}$ & 0.625 & 0.045 \\
Leadership & $-1.057^{*}$ & 0.402 & 0.008 & $-2.173^{* * *}$ & 0.498 & 0 \\
Time & 0.421 & 0.395 & 0.286 & $0.945^{*}$ & 0.521 & 0.07 \\
Credit & $0.718^{*}$ & 0.38 & 0.059 & $2.709^{* * *}$ & 0.642 & 0 \\
\hline
\end{tabular}

*Significant at 0.10 level, **Significant at 0.05 level, ***Significant at 0.01 level

Base variable: male-headed

empowerment among rice farmers using multinomial regression analysis. The table recorded factors that influenced the decision-making between the femaleheaded and male-headed households, which includes extension service, leadership, and credit. Extension service was a significant predictor $(b=0.765$, s.e. $=$ $0.393, \mathrm{p}<0.05)$, as it embraced the decision-making dominated by the female-headed households. Female participants stated that they were involved in the practical training and seminar, which helped them to enhance their knowledge and gain access to information on rice production. They also had direct contact with the extension officers and actively participated more than men in most agricultural meetings organised by the extension office. Similarly, women in Thailand and the Philippines participated more actively than men in most agricultural meetings organised by their local extension offices, which was supported by Akter et al. (2017). Extension and advisory services were the main channels supplying poor farmers with information and new agricultural technologies. They formed the critical vectors for technology dissemination. Farmers who were in contact with the extension agents were presumably more acquainted to information that may not be accessible by others. Globally, millions of women contributed to the national agricultural production and family food security. Consistent studies from Latin America, South Asia and Sub-Saharan Africa showed that rural women farmers were more familiar to access agricultural extension services than men (Haile, 2016).

In addition, leadership displayed a negative significant relationship with the decision-making made by female-headed household ( $b=-1.057$, s.e. $=0.402, p$ $<0.01)$. Female farmers were less confident in publicly speaking out or when they were asked to give suggestions on crucial decisions regarding agricultural activities, policies, or recommendations to stakeholders. In other words, the women farmers' communication skills were lower than men's in the farmers' organisations. Similarly, Ragsdale et al. (2018) found that more women lacked sufficient confidence and uncomfortable compared to men in speaking publicly or open debate. Their results revealed that female farmers had less decision-making power when they were a part of an agricultural organisation, which indicated that they had a lesser presence or leadership skills in a community. Therefore, the lower number of women in agricultural groups' leadership positions may reflect the fact that women in groups were not empowered and had not achieved personal empowerment.

Meanwhile, credit was a significant predictor $(\mathrm{b}=$ 0.718 , s.e. $=0.380, p<0.05)$ that influenced the decision -making made by female-headed households. Female participants mentioned that they usually made their own decisions regarding the use of incomes from agricultural production. Additionally, they took out a loan or borrowed money from the creditor or family to increase paddy yields or buying more inputs. Likewise, Malapit et al. (2019) found that most women had adequate empowerment in decision-making for financing services and credits for the agricultural farms. Access to credit may provide a powerful impact on the empowerment of women. Their involvement in income-generating activities and access to credit were believed to boost their role in household negotiations, thus, allowing them to influence more significant strategic decisions (Ganle et al., 2015).

\subsubsection{Spouse-headed versus male-headed decision- making}

Meanwhile, extension services appeared to be the most significant predictor $(\mathrm{b}=1.551$, s.e. $=0.536, \mathrm{p}<$ $0.01)$ in the model, as it embraced the decision-making by the spouse rather than the male-headed household. Practical training was typically provided by the extension services or agents on paddy farming techniques, pest and diseases, and management. Female farmers stated that they attended a meeting or training to learn about new strategies and current practices in the field and discussed new approaches in the field with their husbands. This way, both husband and wife or spouse jointly made better decisions and discussions on rice farming. Mudege et al., (2015) in the same way mentioned that both women and men empowerment were strongly connected to the extension services as they 
would simultaneously acquire additional information, gain better market access, enhance knowledge, and adopt new technology.

Land and resources positively $(\mathrm{b}=1.254$, s.e. $=$ $0.625, \mathrm{p}<0.05)$ influenced decision-making by spouses in the model. Female participants emphasised that regardless of the owner's assets' formal status and decisions on the purchase and selling of land, the house or primary family resources were made by their husband. Female participants were also aware of their land ownership status. This result corroborated the finding by Malapit et al. (2020) that women and men empowerment were strongly connected to the land and resources, as most farmers made their decision related to land and resources together.

Leadership was a significant negative predictor $(\mathrm{b}=$ -2.173 , s.e. $=0.498, \mathrm{p}<0.01)$ towards decision-making made by spouse-headed households. Majority male farmers felt comfortable speaking publicly and regularly attended community meetings to keep up with the latest advancements and information about rice cultivation and technology usage. The male-headed household normally becomes a leader to the community groups or the farmers' organisations and was allowed to provide opinions and ideas to the community, more than their female counterparts or spouse. This finding by Akter et al. (2017) mentioned that female farmers in Thailand did not have a prominent leadership role in certain tasks or agricultural communities and some of them depended on their spouse.

Time and drudgery were significant predictors $(b=$ 0.945 , s.e. $=0.521, p<0.05)$ that embraced the decisionmaking by the spouse. The seasonal workload in rice farming was a significant factor affecting women's time distribution. Participants made a joint decision according to the workload, especially during peak seasons. Since there were not enough workers during the peak seasons, particularly in planting and harvesting, the periods in between were categorised by inadequate productive activity. Both female and male farmers worked in rice fields for two months during the planting and harvesting seasons with tasks starting early in the morning to the late evening. Additionally, most decisions were collectively made during this period.

Credit showed a positive significant relationship $(b=$ 2.709 , s.e. $=0.642, \mathrm{p}<0.01)$ with the decision-making by the spouses. Both male-headed and female-headed households were involved in decision-making to advance money from non-governmental organisations, official lenders, friends, or relatives. Men had more experience with rice farming credit needs, whereas women were better acquainted with household spending credit needs.
Similarly, Akter et al. (2017) mentioned that credit decisions were taken through a mutual agreement between the men and women in many Asian countries, such as purchasing agricultural inputs and buying daily household needs. In a particular case, there was a high level of credit dependence in agriculture, primarily due to high input costs for rice farming, including labour costs, seeds, fertilisers, and pesticides. Consequently, this idea developed the spouse's ability to engage in more profitable agricultural aspects such as cash crop production and control over the use of credits.

\subsection{Challenges in increasing the agricultural empowerment among women smallholders}

Table 4 presents the challenges in influencing women's empowerment among smallholders in rice production. The results indicated that inadequate participation in the planning process and community members were the most insurmountable challenge with a mean of 0.805 . These planning processes included preparation for rice planting (land preparation) and management (water, weeding, pesticides application, and fertiliser spraying) were needed to increase rice production. Most female farmers stated that they were not interested in the rice cultivation's planning process and were less involved in the community, which hindered them from being exposed to new knowledge, advancement, and decision-making on rice cultivation. More importantly, Nahayo et al. (2017) revealed that inadequate participation in the planning process was one of the significant constraints of women's involvement in agriculture.

Table 4. Challenges in increasing agricultural empowerment among women rice farmers

\begin{tabular}{|c|c|c|}
\hline Challenges & Mean & $\begin{array}{c}\text { Standard } \\
\text { Deviation }\end{array}$ \\
\hline $\begin{array}{l}\text { Lack of participation in the planning } \\
\text { process and community programmes }\end{array}$ & 0.805 & 0.397 \\
\hline Poor access to finances and credit & 0.78 & 0.415 \\
\hline Lack of training and extension services & 0.775 & 0.431 \\
\hline $\begin{array}{l}\text { Lack of access to agricultural } \\
\text { information and technology }\end{array}$ & 0.775 & 0.431 \\
\hline Low socio-economic factors & 0.67 & 0.471 \\
\hline
\end{tabular}

Regional smallholder farmers in many parts of Malaysia had access to agricultural finance or credit through a variety of channel. Poor access to finances had a mean score of 0.780 , which indicated an insignificant female-headed households' involvement in decisionmaking about what to do with the credits. Females also had less access to financing because of their limited education and high transaction costs. Similarly, Jones et al. (2017) revealed that most female farmers had fewer opportunities or access to finance and savings. 
Therefore, they were less empowered compared to males, which influenced their ability to acquire more significant strategic decisions on household spending and purchasing needs. The lack of training and extension services (mean score of 0.775 ) was also one of the challenges that influenced women's empowerment, with more than half of the respondents in Myanmar and Indonesia had little access to the standard extension service (Akter et al. 2017).

Another challenge faced by women in rice farming was the insufficient agricultural information and knowledge (mean score of 0.775). Female farmers typically possessed less information and experience on fertiliser spraying (time and fertiliser used), pesticides application (time and types of pesticides use), common pest and disease, weeding, variety of seed used, and irrigation and harvesting schedule. They only followed the leader (who were male farmers) or the farmer's group community to manage their rice cultivation.

Lastly, socio-economic factors, such as age, education, and income of the farmers were among the constraints faced by the female-headed household. Women farmers were likely to be affected by lower socio-economic factors, such as limited education and income. The findings of this study showed that the majority of the female farmers only completed secondary school, and their income was in the medium range. Hence, possessing a formal education allowed them to obtain extra knowledge and helped them to achieve a higher economic status and self-confidence, which may encourage more female contributions to decision-making in the farm. In other words, less educated and economically passive women in the workforce would lead them to acquire less decision-making power related to agriculture and household decisions compared to an educated woman (Baliyan, 2014). Thus, Bhat (2015) suggested that education is a landmark for women's empowerment as it enables them to respond to challenges, face their traditional position, and change their lives.

\section{Conclusion}

This study addressed women's empowerment and its challenges in rice production. Variables such as access to extension service, credit, and leadership were identified as the significant factors affecting women's empowerment. Our results revealed that women's empowerment was vital to increase rice productivity as they actively engaged in a variety of tasks related to rice cultivation. The government and non-government organisations (NGO) are urged to strengthen the female farmers' decision-making power in rice production since women's empowerment is objectively crucial to the 2030 SDG5. Therefore, focusing on the roles of women farmers are vital in enabling them to have fair access to the resources, opportunities, and decision-making. Additionally, this idea improves agricultural productivity and income, reduce poverty, hunger, and achieve food security. Our results offer encouragement for the effectiveness of the policies and strategic interventions aimed at stimulating the Malaysian agricultural productivity through women's empowerment. The power to make a crucial extension and credit decisions were the most critical rice production drivers, albeit leadership skills negatively influenced women's empowerment. Hence, women's empowerment positively impacted agriculture activities and suggested a great scope of possible interventions. This scope includes financial mechanisms, such as digital savings accounts, affordable credit schemes, asset-building mechanisms, and programmes facilitating the formation of strong community associations for women, which enhances leadership and communication skills. In conclusion, while our study pointed towards the positive effect of women's empowerment on rice production decisionmaking, the cross-sectional nature of our data did not support the analysis of the impacts associated with women's empowerment and yield. Furthermore, our data were not nationally representative, which might not reflect the women's empowerment status across Malaysia. Hence, further studies on Malaysia's representative is necessary to understand the relationship between women's empowerment and agricultural productivity fully.

\section{References}

Abaide, E.R., Tres, M.V., Zabot, G.L. and Mazutti, M.A. (2019). Biomass and Bioenergy Reasons for processing of rice coproducts: Reality and expectations. Biomass and Bioenergy, 120, 240-256. https://doi.org/10.1016/j.biombioe.2018.11.032

Abdul Fatah, F. and von Cramon Tubadel, S. (2017). Profitability and Competitiveness of Rice Farming in Malaysia: A Policy Analysis Matrix. Asian Journal of Agriculture and Development, 14(2), 32-47. https://ageconsearch.umn.edu/record/265764

Akter, S., Rutsaert, P., Luis, J., Me, N., Su, S., Raharjo, B. and Pustika, A. (2017). Women's empowerment and gender equity in agriculture: A different perspective from Southeast Asia. Food Policy, 69, 270-279. https:// doi.org/10.1016/j.foodpol.2017.05.003

Alam, M.M., Siwar, C., Murad, M.W., Molla, R.I. and Mohd Ekhwan. T. (2010). Socioeconomic Profile of Farmer in Malaysia: Study on Integrated 
Agricultural Development Area in North-West Selangor. Agricultural Economics and Rural Development, 7(2), 249-265. file:///C:/Users/USER/ Downloads/

J13.SocioeconomicProfileofFarmer_AERD.pdf

Alkire, S., Meinzen-Dick, R.S., Peterman, A., Quisumbing, A.R., Seymour, G. and Vaz, A. (2013). The women's empowerment in agriculture index. World, 52, 71-91. https://doi.org/10.1016/ j.worlddev.2013.06.007

Aris, N.F.M. and Abdul Fatah, F. (2019). Cost and Return Analysis of System of Rice Intensification (SRI): Evidence from Major Rice Producing Areas in Malaysia. International Journal of Supply Chain Management, 8(3), 541-546. https:// ojs.excelingtech.co.uk/index.php/IJSCM/article/ view/3239/1677

Baliyan, K. (2014). Factors Affecting Participation of Woman in Household Decision Making: Implication for Family Welfare and Agriculture Development. Retrieved from website: https://www.indiastat.com/ SOCIO_PDF/103/fulltext.pdf

Bhat, R.A. (2015). Role of Education in the Empowerment of Women in India. Journal of Education and Practice, 6(10), 188-192.

Diiro, G.M., Seymour, G., Kassie, M., Muricho, G. and Muriithi, B.W. (2018) Women's Empowerment in Agriculture and Agricultural Productivity: Evidence from Rural Maize Farmer Households in Western Kenya. PLoS ONE, 13(5), e0197995. https:// doi.org/10.1371/journal.pone.0197995

Ganle, J.K., Afriyie, K. and Segbefia, A.Y. (2015). Microcredit: Empowerment and Disempowerment of Rural Women in Ghana. World Development, 66, 335-345.

j.worlddev.2014.08.027

Goldstein, M. and Udry, C. (2008). The profits of power: land rights and agricultural Investment in Ghana. Journal of Political Economy, 116(6), 981-1022. https://doi.org/10.1086/595561

Gupta, S. (2016). Guidelines for Assessing Women's Empowerment in Agriculture: Operational Manual for Using the Women's Empowerment in Agriculture Index (WEAI) $\mathrm{n}$ Field Research. Training Manual No.2. New Delhi, India: TARINA Center of Excellence, Tata-Cornell Institute for Agriculture and Nutrition.

Haile, F. (2016). Factors Affecting Women Farmers' Participation in Agricultural Extension Services for Improving the Production in Rural District of Dendi West Shoa Zone, Ethiopia. Journal of Culture, Society and Development, 21, 30-41. https://
doi.org/10.15740/HAS/IJHSECM/3.2/59-71

Haimid, M.T., Rozana, N. and Mohd, N. (2016). Women entrepreneurs in the agriculture sector: Issues and challenges. Economic and Technology Management Review, 11, 53-61. http://etmr.mardi.gov.my/ Content/ETMR\%20Vol.\%2011a(2016)/Tarmizi.pdf

Holland, C. and Rammohan, A. (2019). Rural women's empowerment and children's food and nutrition security in Bangladesh. World Development, 124, 1046483.

https://doi.org/10.1016/

j.worlddev.2019.104648

Jones, N., Holmes, R., Presler-Marshall, E. and Stavropoulou, M. (2017). Transforming gender constraints in the agricultural sector: The potential of social protection programmes. Global Food Security, 12, 89-95. https://doi.org/10.1016/j.gfs.2016.09.004

Kilic, T., Palacios-Lopez, A. and Goldstein, M. (2013). Caught in a productivity trap: A distributional perspective on gender differences in Malawian agriculture. Policy Research Working Paper, No. 6381, World Bank Group E-book. https:// doi.org/10.1596/1813-9450-6381

Malapit, H., Quisumbing, A., Meinzen-dick, R., Seymour, G., Martinez, E.M., Heckert, J., Rubin, D., Vaz, A., Yount, K.M., Assets, A., Phase, P. and Study, G. (2019). Development of the project-level Women 's Empowerment in Agriculture Index (proWEAI). World Development, 122, 675-692. https:// doi.org/10.1016/j.worlddev.2019.06.018

Malapit, H., Ragasa, C., Martinez, E.M., Rubin, D., Seymour, G. and Quisumbing, A. (2020). Empowerment in agricultural value chains: Mixed methods evidence from the Philippines. Journal of Rural Studies, 76, 1-14. https://doi.org/10.1016/ j.jrurstud.2020.04.003

Muazu, A., Yahya, A. and Ishak, W.I.W. (2015). Energy audit for sustainable wetland paddy cultivation in Malaysia. Energy, 87, 182-191. https:// doi.org/10.1016/j.energy.2015.04.066

Mudege, N.N., Chevo, T., Nyekanyeka, T., Kapalasa, E. and Demo, P. (2015). Gender Norms and Access to Extension Services and Training among Potato Farmers in Dedza and Ntcheu in Malawi. The Journal of Agricultural Education and Extension, 22 (3), 291-305. https:// doi.org/10.1080/1389224X.2015.1038282

Nahayo, A., Omondi, M.O., Zhang, X.-H., Li, L.Q-., PAN, G-X. and Joseph, S. (2017). Factors influencing farmers' participation in crop intensification program in Rwanda. Journal of Integrative Agriculture, 16(6), 1406-1416. https:// doi.org/10.1016/S2095-3119(16)61555-1 
Peterman, A., Quisumbing, A.R., Behrman, J. and Nkonya, E. (2011). Understanding the complexities surrounding gender differences in agricultural productivity in Nigeria and Uganda. Journal of Development Studies, 47(10), 1482-1509. https:// doi.org/10.1080/00220388.2010.536222

Quisumbing, A.R. and Otsuka, K. (2001). Land inheritance and schooling in matrilineal societies: evidence from Sumatra. World Development, 29(12), 2093-2110. https://doi.org/10.1016/S0305-750X(01) 00086-9

Ragsdale, K., Read-Wahidi, M.R., Wei, T., Martey, E. and Goldsmith, P. (2018). Using the WEAI + to explore gender equity and agricultural empowerment: Baseline evidence among men and women smallholder farmers in Ghana's Northern Region. Journal of Rural Studies, 64, 123-134. https://doi.org/10.1016/j.jrurstud.2018.09.013

Rajamoorthy, Y., Rahim, K.B.A. and Munusamy, S. (2015). Rice Industry in Malaysia: Challenges, Policies and Implications. Procedia Economics and Finance, 31(15), 861-867. https://doi.org/10.1016/ s2212-5671(15)01183-1

Shamsudin, M.N., Ramli, N.N., Radam, A. and Mohamed, Z. (2015). The Impact of Fertiliser Subsidy and New Variety of Paddy on Malaysian Paddy/Rice Industry Using a System Dynamics Approach. International Journal of Social Science and Humanity, 2(3), 213-219. http://ijssh.org/ papers/98-CH224.pdf

Singh, S., Kushwah, S., Singh, V.B., Daipuria, O.P., Student, P.D., Education, E. and Rvskvv, C. (2015). Factor Affecting the Participation of Rural Women in Agricultural Activities. Indian Research Journal of Extension Education, 15(1), 81-83.

Yount, K.M., Cheong, Y.F., Maxwell, L., Heckert, J., Martinez, E.M. and Seymour, G. (2019). Measurement properties of the project-level Women's Empowerment in Agriculture Index. World Development, 124, 104639. https:// doi.org/10.1016/j.worlddev.2019.104639 